\title{
IDENTIFIKASI TIGA KELOMPOK IKAN BELIDA (Chitala lopis) \\ DI SUNGAI TULANG BAWANG, KAMPAR, DAN KAPUAS DENGAN PENDEKATAN BIOMETRIK
}

\author{
Mas Tri Djoko Sunarno"), Arif Wibowo'), dan Subagja1) \\ 1) Peneliti pada Balai Riset Perikanan Perairan Umum, Palembang
}

Teregristrasi I tanggal: 12 Desember 2006; Diterima setelah perbaikan tanggal: 18 Juni 2007; Disetujui terbit tanggal: 5 Juli 2007

\begin{abstract}
ABSTRAK
Aktivitas penangkapan lebih (over fishing), penggunaan alat tangkap yang tidak ramah lingkungan, dan perubahan kondisi lingkungan perairan menyebabkan kelestarian ikan belida (Chitala lopis) menjadi terancam. Untuk itu, diperlukan upaya konservasi yang tepat untuk melestarikan ikan ini. Tahap awal adalah melalui penelitian morfologi. Tujuan penelitian adalah mengidentifikasi keragaman jenis ikan belida di Sungai Tulang Bawang (Lampung), Kampar (Riau), dan Kapuas (Kalimantan Barat) melalui variasi bentuk tubuh dan karakter morfologi pembeda. Penentuan lokasi pengambilan contoh dilakukan secara purposive sampling. Untuk setiap spesies pengambilan contoh per lokasi berkisar antara 10 sampai dengan 30 spesimen. Contoh ditandai (tagging) dituliskan kode spesimen dan lokasi kemudian diawetkan dengan direndam larutan alkohol $75 \%$. Pengukuran spesimen dengan digital kaliper di sisi tubuh sebelah kiri, pada 28 karakter morfologi. Data yang diperoleh distandarisasi, disajikan dalam \% SL dan \% HL yang merupakan subyek principal component analysis menggunakan Statistik 6.0. Tahap ke-2, menggunakan analysis diskriminan untuk mengisolasi ke tipe spesimen tadi menjadi kelompok yang terpisah, melihat karakter morfologi dominan (factor score coefficient) akhirnya hanya 1 karakter yang paling dominan. Terdapat 3 kelompok ikan belida yang memperlihatkan penampilan morfologi yang berbeda, dari ke-3 lokasi yang diamati. Pembeda ke-3 kelompok ikan belida di 3 sungai tersebut adalah peduncle length (tinggi punguk) (\% HL) dan mouth width (lebar mulut) (\% SL).
\end{abstract}

KATAKUNCI: ikan belida, kelompok, Sungai Tulang Bawang, Sungai Kampar, Sungai Kapuas, biometrik

ABSTRACT: Identification three groups of belida fish (Chitala Lopis) in Tulang Bawang (Lampung), Kampar (Riau), and Kapuas (Kalimantan Barat) rivers using biometric approach. By: Mas Tri Djoko Sunarno, Arif Wibowo, and Subagja

Over fishing activities, implementation of unfriendly environmental gears and altered aquatic environment condition have endangered the feather fish (Chitala lopis). Therefore appropriate conservation efforts will be needed and research on morphology variance can be the starting point. The objective of research is to indentify the diversity of feather fish in Tulang Bawang (Lampung), Kampar (Riau), and Kapuas (Kalimantan Barat) rivers through body shape variations and it's main morphology characters. Sampling station were chosen based on purposive sampling. Whatever possible, the number of samples range between 10 to 30 in every station sampling. Samples were tagged with specimen code and location, and then preserve using alcohol $75 \%$. Measurements were made manually using dial calipers correct to tenth milimetre. Measurements were made on the left side of body, 28 point to point measurements. These characters were standardized, perform in \% SL and \% HL subject to principal component analysis using Statistica 6.0. Futher analysis using discriminant analysis to isolate 3 type specimens, find out the dominant characters, and finally see the most dominance characters. There are 3 groups of feather fish's that performed different morphology characters from the sampling site, where as peduncle length (\% HL) and mouth width (\% SL) were the dominance characters.

\section{KEYWORDS: $\quad$ feather fish, group, Tulang Bawang, Kampar, Kapuas Rivers, biometric}

\section{PENDAHULUAN}

Jumlah spesies ikan di dunia sekitar 28.500 spesies (Nelson, 1994). Dari jumlah tersebut, ikan laut menyusun $58 \%$, ikan air tawar menyusun $41 \%$, dan $1 \%$ sisa berada di antara 2 lingkungan tersebut (Cohen, 1970 dalam Mustafa, 1999). Sejumlah besar spesies ikan air tawar terdapat di daerah tropis dan Indonesia merupakan negara yang memiliki keanekaragaman hayati ikan yang paling besar dengan jumlah spesies lebih dari 1.300 spesies (Kottelat \& Whitten, 1996).

Dari berbagai spesies ikan air tawar yang menghuni perairan tawar Indonesia, beberapa diantaranya termasuk

Kosrespondensi penulis: 
ke dalam kelompok ikan asli Indonesia yang penting dan memiliki nilai ekonomis yang tinggi misal ikan belida (Chitala lopis). Di Sumatera Selatan, ikan belida ditetapkan sebagai maskot fauna oleh pemerintah daerah setempat. Selain itu, juga digunakan sebagai bahan baku untuk pembuatan makanan khas daerah seperti empekempek, kerupuk, kemplang, dan bahan pangan yang lain. Akhir-akhir ini ada kecendrungan ikan belida ini dimanfaatkan juga sebagai ikan hias, sehingga ikan belida mulai banyak dijumpai di akuarium. Hal ini, disebabkan oleh bentuk yang indah (menyerupai ikan purba dengan rumbai yang indah) dan merupakan ikan langka Indonesia.

Adanya aktivitas penangkapan lebih (over fishing), penggunaan alat tangkap yang tidak ramah lingkungan dan perubahan kondisi lingkungan perairan menyebabkan kelestarian jenis ikan ini menjadi terancam (Pollnac \& Malvestuto, 1991). Lebih jauh, ikan belida sudah termasuk ikan air tawar yang telah dilindungi, sehingga upaya konservasi sangat diperlukan dan menjadi sesuatu yang mendesak demi kelestarian jenis ikan ini. Selain itu, dipandang dari aspek biologi, konservasi spesies sangat penting karena fungsi yang signifikan terhadap komunitas akuatik dan sistem akuatik dari keseluruhan biosfer.

Upaya konservasi ikan belida di masa depan sangat membutuhkan data biologi termasuk informasi tentang keragaman jenis, hasil dari variasi geografi (faktor lingkungan) dan isolasi reproduksi. Keragaman jenis ditunjukkan melalui bentuk tubuh (morfologi) yang secara langsung menggambarkan sifat efisiensi makan, performa gerakkan, kemampuan sebagai predator dan kesuksesan reproduksi. Ke semua sifat ini merupakan sifat-sifat penting yang menunjukkan tingkat kemampuan jenis tersebut untuk dapat bertahan hidup (fitness).

Penelitian ini bertujuan untuk mengidentifikasi keragaman jenis ikan belida di Sungai Tulang Bawang (Lampung), Kampar (Riau), dan Kapuas (Kalimantan Barat) melalui variasi bentuk tubuh dan karakter morfologi pembeda. Diharapkan informasi ini menjadi masukkan yang berharga dalam program konservasi ikan belida.

\section{BAHAN DAN METODE}

Penentuan lokasi pengambilan contoh di 3 sungai tersebut dilakukan secara purposive sampling, pada daerah yang ada ikan belida dan diperkirakan memiliki skala geografik yang berbeda. Untuk setiap spesies ikan belida, dilakukan pengambilan contoh dengan jumlah perlokasi berkisar antara 10 sampai dengan 30 spesimen. Alat tangkap yang digunakan adalah pancing, jaring, jala, dan teban. Contoh tersebut (carcass) selanjutnya ditandai (tagging) dituliskan kode spesimen dan lokasi dengan menggunakan dymo machine contoh kampar 001. Contoh yang sudah ditandai di diawetkan dengan cara direndam larutan alkohol $75 \%$.

Pengukuran spesimen dilakukan dengan menggunakan digital caliper yang memiliki ketelitian sampai dengan $0,10 \mathrm{~mm}$, pada 28 karakter morfologi bentuk badan (Gambar 1), di bagian sisi sebelah kiri. Data yang diperoleh kemudian distandarisasi dan disajikan dalam bentuk \% standard length dan \% head length yang merupakan subyek principal component analysis untuk melihat grouping spesimen dalam tipe specimen menggunakan software Statistica 6.0. Principal component yang digunakan adalah principal component II, III, IV, dan V, karena principal component tersebut menunjukkan bentuk, bukan principal component I yang menampilkan ukuran. Tahap ke-2, dilakukan dengan menggunakan analisis deskriminan, analisis deskriminan nanti akan mengisolasi ke-3 tipe spesimen tadi menjadi kelompok yang terpisah. Analisis lebih lanjut melihat karakter morfologi dominan (factor score coefficient) sebagai pembeda sifat, untuk kemudian pada akhirnya hanya 1 karakter yang paling dominan di masing-masing principal component yang diamati.

\section{HASIL DAN BAHASAN}

Keragaman adalah bagian dari taksonomi yang merupakan elemen dasar program konservasi (Stiassny \& Pinna, 1994). Pendekatan untuk melihat keberagaman dapat dilakukan melalui morfologi, fisiologi, tingkah laku, dan molecular (Mayr \& Ashlock, 1991), walaupun kadang dianggap sebagai metode konvensional, pendekatan morfologi merupakan metode yang valid. Dalam banyak kasus pendekatan morfologi sangat berguna memisahkan tingkatan yang berbeda di lapangan (Gustiano, 2003).

Pendekatan morfologi diaplikasikan dengan cara atau dalam bentuk biometrik atau morfometrik. Morfologi secara umum terdiri atas 1 set teknik untuk menggambarkan bentuk tubuh luar (Reist, 1986). Informasi yang dikumpulkan selanjutnya akan digunakan sebagai panduan untuk membedakan bentuk, populasi, spesies, atau komunitas. Tidak ada protokol untuk memilih karakter yang dipelajari kecuali contoh harus banyak dan bentuk tubuh utuh (Strauss \& Bookstein, 1982). Ikan yang dijadikan contoh memiliki ukuran bobot lebih dari $1 \mathrm{~kg}$ (jika memungkinkan), tidak dilakukan pengambilan contoh berdasarkan pada jenis kelamin dan pada tahap juveniles. Hal ini, untuk mengurangi variasi sebagai akibat sexual dimorphism dan ontogenetic allometry (Hood \& Heins, 2000). 

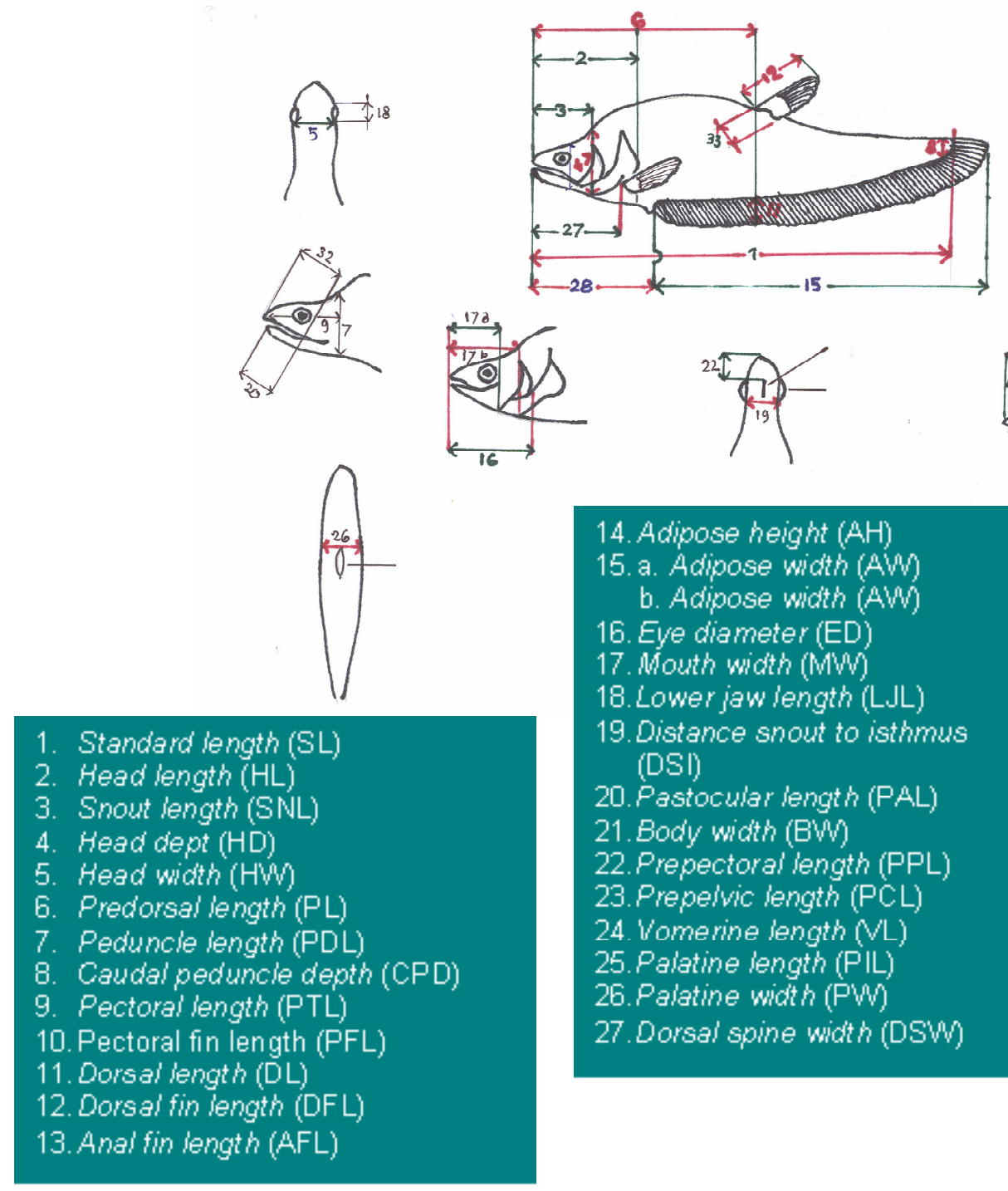

\section{Adipose height (AH)}

15. a. Adipose widt (AW) b. Adipose width (AW)

16. Eye diameter (ED)

17. Wouth width (MW)

18. Lower jaw iength (LJL)

19. Distance snout to isthmus (DSI)

20. Pastocular length (PAL)

21. Body width (BW)

22. Prepectoral length (PPL)

23. Prepelvic length (PCL)

24. Vomerine length $(\mathrm{VL})$

25. Palatine length (PIL)

26. Palatine width ( $\mathrm{PW})$

27. Dorsal spine width (DSW)

Gambar 1. Pengamatan morfometrik ikan belida.

Figure 1. Morfometric observation of belida fish.

Secara visual, (kualitatif) bentuk tubuh (morfologi) ikan belida, terdapat perbedaan di antara spesies atau individu (Gambar 2). Perbedaan terutama terlihat pada bentuk tengkuk dan lebar badan. Hasil tampilan visual ini akan dijelaskan secara kuantitatif dengan analisis PCA dan analisis deskriminan. Pengamatan pada 22 karakter morfologi dari 49 spesimen ikan belida, berdasarkan pada analisis komponen utama menunjukkan ikan belida di Sungai Tulang Bawang, Kampar, dan Kapuas dikelompokkan menjadi 3 kelompok taksonomik yang berbeda, yaitu tipe 1, 2, dan 3 (Gambar 3). PCA adalah salah satu metode multivariat yang paling sering digunakan untuk permasalahan biologi dan sejauh ini merupakan metode yang paling luas digunakan untuk analisis morfometrik (Humphries et al., 1981). Pengelompokkan pada Gambar 3, berdasarkan pada cosinus kuadrat yang memperlihatkan keeratan hubungan. Pengelompokkan berdasarkan pada penempatan obyek dalam kelompok sedemikian rupa, sehingga anggota masing-masing kelompok memiliki hubungan kedekatan yang lebih tinggi dengan anggota yang lain yang dalam satu kelompok dibanding dengan kelompok yang lain (Mayr \& Ashlock, 1991), sehingga tingkat kesamaan menjadi kriteria. 


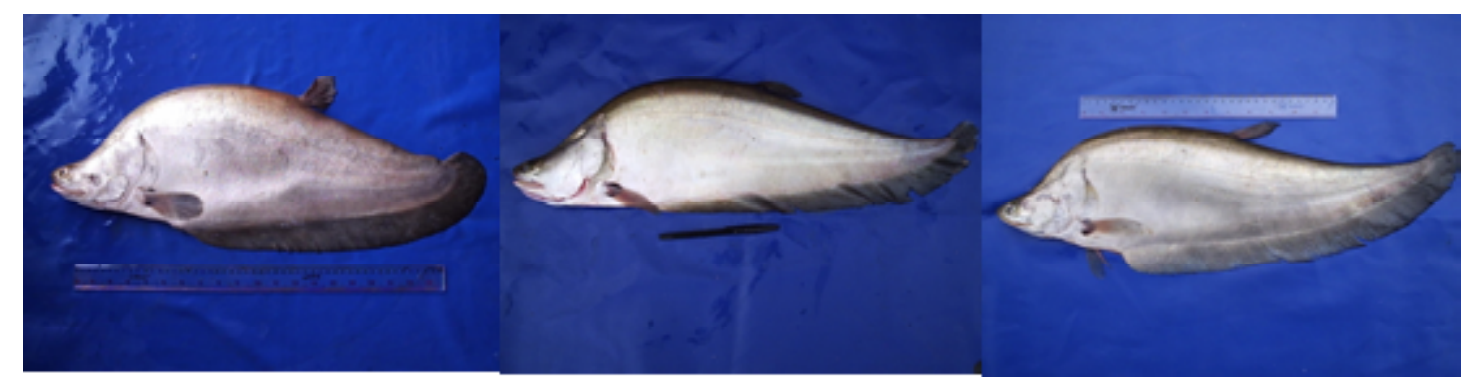

Gambar 2. Bentuk morfologi ikan belida secara visual terdapat perbedaan tengkuk dan lebar badan. Figure 2. Morfologi shape of belida fish by visual there are different in peduncle length and mounth width.

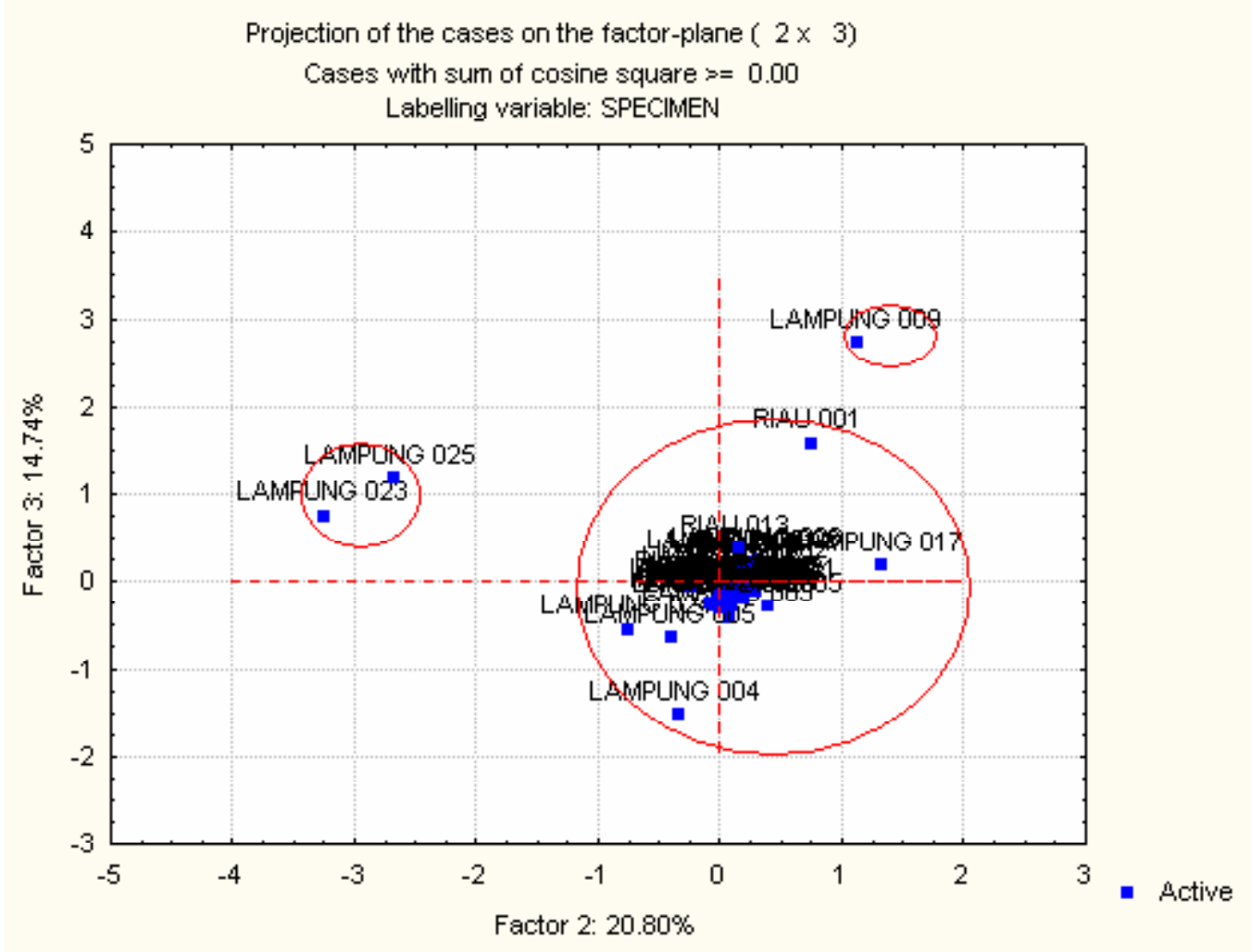

Gambar 3. Tiga kelompok ikan belida berdasarkan pada PCA.

Figure 3. Three group of belida fish depend on PCA.

Analisis lebih lanjut dengan menggunakan analisis deskriminan mengisolasi tipe spesimen ini secara alami menjadi 3 kelompok ikan belida yang berbeda (Gambar 4). Ikan belida yang termasuk kelompok I berada pada sektor positif PC II dan sektor negatif PC III, kelompok II berkelompok pada sektor positif PC I dan bercampur antara sektor positif dan negatif pada PC III, sedangkan kelompok 3 mengelompok pada sektor positif dan negatif pada PC II dan PC III.

Di duga variasi musiman dan kondisi lingkungan memberi kontribusi terjadi perbedaan. James (1970,
1983); Johnston \& Fleischer (1981) mengatakan faktor lingkungan merupakan salah satu faktor yang mempengaruhi ukuran spesies, baik sebagian maupun seluruh. Panjang tubuh ikan dewasa merupakan pengaruh faktor lingkungan khusus selama ontogeny, yang paling tidak mencerminkan sifat dan kemampuan spesies tersebut, sebagai contoh kemampuan mencari makan (Næsje et al., 2004). Selain itu, isolasi geografis antara Pulau Kalimantan dan Sumatera diduga juga memberikan kontribusi terjadi perbedaan. Vuorinen et al. (1991) memperlihatkan terjadi perbedaan genetik yang besar akibat isolasi geografis, pada kurun waktu kurang dari 
100 tahun. Pada T. thymallus, terjadi perbedaan karakter genetik dan fenotipe yang signifikan pada populasi yang telah terpisah, disebabkan oleh seleksi alam kurang dari 125 tahun (Koskinen et al., 2002). Kekuatan seleksi alam dan atau seleksi seksual menghasilkan perbedaan ke arah evolusi pada Guppies, Poecilia reticulata yang merupakan mekanisme adaptasi sebagai respon ikan dari kondisi lingkungan lokal (Endler \& Houde, 1995). Isolasi dapat juga menjadi mediasi lewat genetic drift dan founder effects (Tilley et al., 1990).

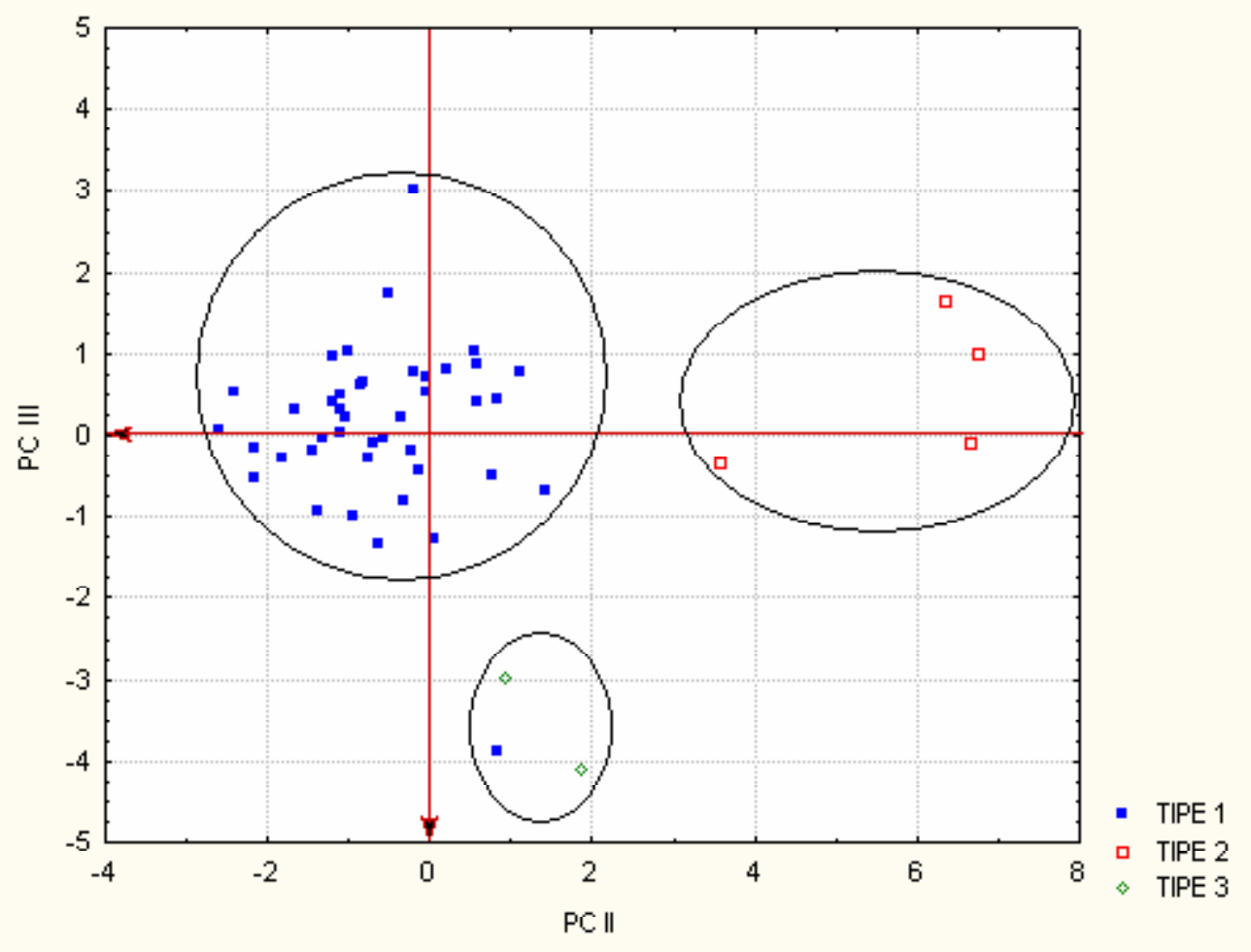

Gambar 4. Hasil analisis deskriminan yang mengelompokkan belida dalam 3 kelompok.

Figure 4. Result of descreminant analysis group belida in three groups.

Untuk melihat sumbangan masing-masing karakter (28 karakter) terhadap perbedaan 3 kelompok, ditampilkan factor score coeficient atau faktor loading pada PC II dan III (Tabel 1). Faktor loading mengindikasikan bagaimana variabel atau karakter berhubungan dengan PC. Secara umum, besaran loading melukiskan keeratan hubungan variabel dengan faktor, yang mana menandakan arah alometri terhadap ukuran umum (Schaefer, 1991). Semakin besar faktor loading (apakah positif atau negatif) dari 1 variabel dari PC yang dilihat, semakin tinggi korelasi dengan PC ini, semakin tinggi kontribusi dalam membedakan dengan spesies lain atau populasi.

Berdasarkan pada tabel tersebut, maka dapat dilihat karakter dominan yang muncul yang merupakan karakter pembeda kelompok, terlihat pada Table 2. 
Tabel 1. Nilai koefisien faktor, berdasarkan pada kovarian pada PC II dan III (data dalam \% standard length dan \% head length)

Table 1. Coefficients score factor depending on covariances on PC II and III (data in \% standard length and $\%$ head length)

\begin{tabular}{cccccc}
\hline & Faktor $\mathbf{1}$ & Faktor $\mathbf{2}$ & Faktor $\mathbf{3}$ & Faktor $\mathbf{4}$ & Faktor $\mathbf{5}$ \\
\hline HD & 0,024943 & $-0,06026$ & 0,052582 & 1,617851 & 0,06197 \\
HW & $-0,002439$ & $-0,06622$ & $0,156156^{* *}$ & $-0,076275$ & 0,502736 \\
PL & 0,240688 & $-0,04134$ & $-0,013161$ & $-0,059877$ & $-0,003938$ \\
PDL & 0,002336 & $0,53625^{* *}$ & 0,017408 & 0,064024 & $-0,016422$ \\
CPD & $-0,012917$ & 0,00869 & $-0,144633^{* *}$ & 0,036512 & $-0,083758$ \\
PTL & 0,034598 & $-0,07174$ & 0,070109 & $-0,432276$ & $-0,002119$ \\
AFW & 0,009995 & 0,07161 & 0,018132 & $-0,181354$ & 0,512937 \\
DFL & 0,022297 & $-1,13575^{* *}$ & 0,076484 & 0,030181 & 0,280136 \\
AFL & 0,271226 & 0,01113 & $0,616998^{* *}$ & $-0,219758$ & $-0,044448$ \\
AH & 0,003656 & $-0,35510^{* *}$ & $-0,026279$ & $-0,691969$ & 0,361326 \\
DSI & 0,04737 & 0,02747 & $-0,125011^{* *}$ & $-0,041254$ & $-0,020663$ \\
PAL & 0,023454 & $-0,0567$ & $-0,011618$ & 1,776709 & $-0,033944$ \\
MBD & $-0,009918$ & 0,04023 & $-0,046456$ & $-0,099429$ & 0,470282 \\
PPL & 0,059247 & 0,03144 & $-0,04012$ & 0,158303 & 0,122268 \\
PFL & 0,093772 & 0,09776 & 0,01987 & $-0,108601$ & $-0,042776$ \\
DSW & $-0,014808$ & $0,10358^{* *}$ & $-0,048177$ & 0,034659 & 0,054179 \\
HL & 0,072878 & $-0,06931$ & $-0,100459^{* *}$ & $-0,130804$ & 0,00136 \\
SNL & $-0,974385$ & 0,06441 & 0,022802 & $-0,289835$ & 0,173828 \\
DSO & 0,304264 & $-0,00716$ & $-0,055095$ & 0,025922 & 0,267014 \\
UJL & $-0,033213$ & 0,14502 & $-0,378076^{* *}$ & $-0,215602$ & $-0,058777$ \\
ED & 0,04841 & $-0,08466$ & $-0,299128^{* *}$ & 0,160351 & 0,112456 \\
MW & $-0,165172$ & 0,01997 & $-0,717736^{* *}$ & $-0,316342$ & 0,617258 \\
LJL & $-0,000304$ & $0,55469^{* *}$ & $-0,05511$ & 0,003029 & 0,297844 \\
\hline
\end{tabular}

Keterangan/Remarks: ${ }^{* *}=$ karakter dominan

Tabel 2. Karakter dominan pembeda sifat populasi ikan belida yang diamati

Table 2. Dominant characters of belida fish population observed

\section{Faktor 2}

Peduncle length (tinggi punguk)

Dorsal fin length (panjang sirip punggung)

Adipose heighth (jarak antara mulut atas dengan bukaan insang pertama)

Dorsal spine width (lebar sirip punggung)

Lower jaw length (panjang mulut bawah)

\section{Faktor 3}

Head width (lebar mulut)

Caudal peduncle depth (tinggi tubuh sebelum sirip di ekor)

Anal fin length (panjang sirip ekor)

Distance snout to ishmus (jarak ishmus dengan mulut atas)

Head length (panjang kepala)

Upper jaw length (panjang rahang atas)

Eyes diameter (diameter mata)

Mouth width (lebar mulut) 
Analisis akhir karakter dominan dengan diskriminan menunjukkan pembeda ke - 3 kelompok ikan belida adalah peduncle length (tinggi punguk) dan mouth width (lebar mulut) (Gambar 5). Perbedaan pada tinggi punguk (\% standard length) diduga disebabkan oleh pola migrasi musiman dan perkembangan otot yang berbeda (Barlow, 1980), sedangkan perbedaan kelompok berdasarkan pada lebar mulut (PC III), mengindikasikan bahwa faktor ketersediaan makanan dan cara mencari makan (memasukkan ke dalam mulut) di habitat belida merupakan pembeda utama di 3 lokasi tersebut. Hespenheide (1973); Schluter \& Grant (1984) mengatakan bahwa karakter lebar mulut berhubungan dengan ukuran makanan dan berbagai aspek makanan.

Upaya manajemen konservasi ikan belida di masa depan dapat mempertimbangkan keberadaan ke-3 populasi ini. Ada manajemen yang berbeda dalam upaya 3 populasi ini yaitu untuk menjaga kelestarian genetik dan keberhasilan program breeding atau domestikasi.

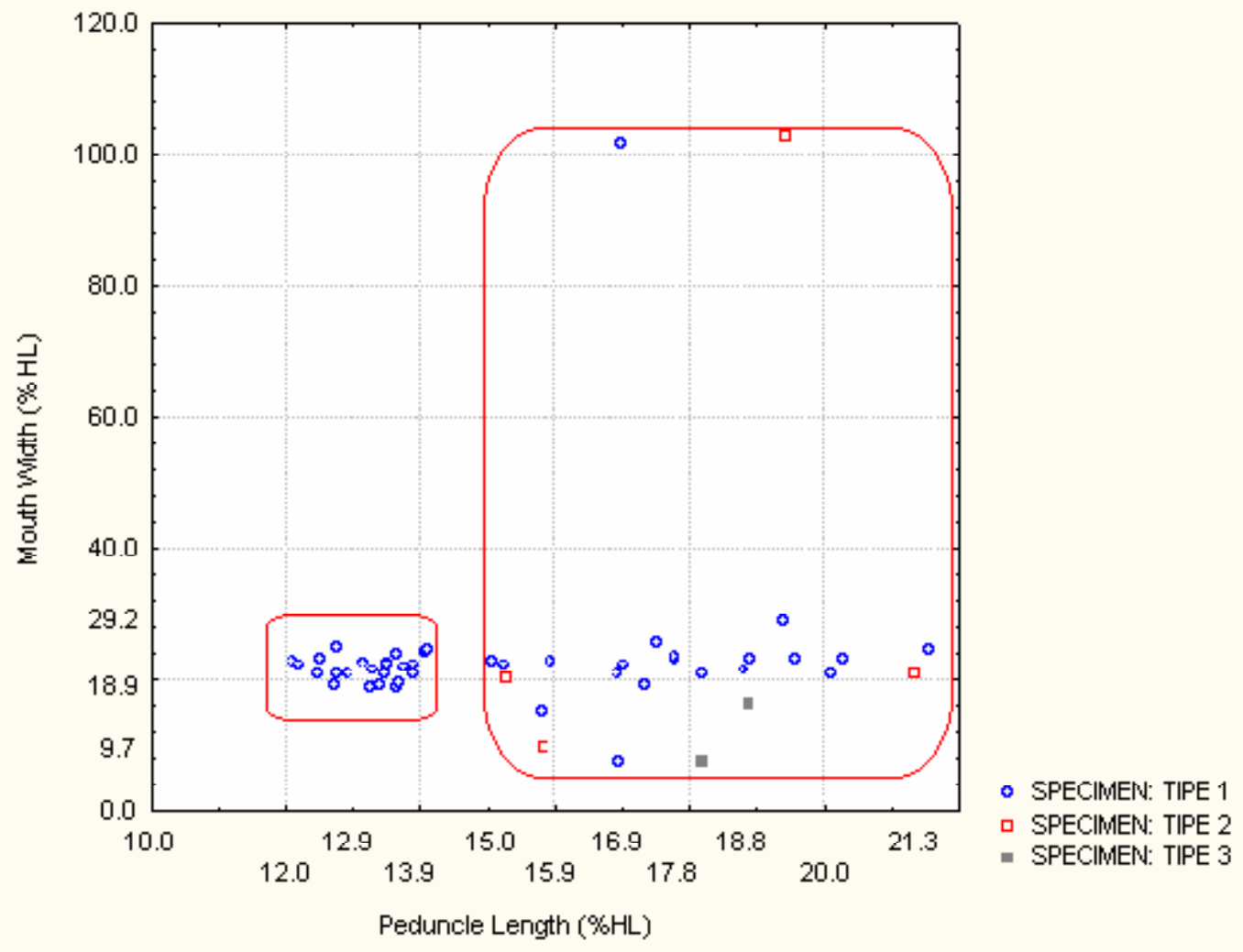

Gambar 5. Karakter pembeda ikan belida di 3 lokasi sungai.

Figure 5. Difference character of belida fish in 3 rivers location.

\section{KESIMPULAN}

1. Ikan belida di Sungai Tulang Bawang (Lampung), Kampar (Riau), dan Kapuas (Kalimantan Barat) terisolasi menjadi 3 kelompok yang berbeda. Pembeda ke-3 kelompok ikan belida di 3 sungai tersebut adalah peduncle length (tinggi punguk) $(\% \mathrm{HL})$ dan mouth width (lebar mulut) (\% SL).

2. Upaya manajemen konservasi ikan belida di masa depan dapat mempertimbangkan keberadaan ke-3 populasi ini. Ada manajemen yang berbeda dalam upaya 3 populasi ini yaitu untuk menjaga kelestarian genetik dan keberhasilan program breeding atau domestikasi.

\section{PERSANTUNAN}

Kegiatan dari hasil riset karakteristik habitat dan identifikasi ikan belida (Chitala lopis) di perairan umum, Indonesia, T.A. 2005, di Anggaran Pendapatan Belanja Negara.

\section{DAFTAR PUSTAKA}

Barlow, G. 1980. Adaptive responses in skeletal characters of the New World population of Passer montanus. Proc. Int. Omithol. Congr. 17: 1143-I 149. 
Endler, J. A. \& Houde, A. E. 1995. Geographic variation in female preferences for male traits in Poecilia reticulata. Evolution 49: 456-468.

Gustiano, R. 2003. Taxonomy and phylogeny of Pangasiidae Catfishes from Asia (Ostariophysi, Siluriformes). Thesis For The Doctor's Degree (Ph.D.). Katholieke Universiteit Leuven. Leuven. Belgium. 296 p.

Hespenheide, H. A. 1973. Ecological inferences from morphological data. Ann. Rev. Ecol. Syst. 4:213-229.

Hood, C. S. \& Heins, D. C. 2000. Ontogeny and allometry of body shape in the blacktail shiner, Cyprinella venusta. Copeia 2000: 270-275.

Humphries J. M., Bookstein F. L., Chernoff B., Smith G. R., Elder R. L., \& S. G. Poss (1981). Multivariate discrimination by shape in relation to size. Syst. Zool. 30 (3): 291-308.

James, F. C. 1970. Geographic size variation in birds and Its relationship to climate. Ecology 51: 365-390.

1983. Environmental component of morphological differentiation in birds. Science 221: 184-186.

Johnston, R. F. \& R. C. Fleischer. 1981. Overwinter mortality and sexual size dimorphism in the house sparrow. Auk. 98: 503-5 11.

Koskinen, M. T., T. O. Haugen, \& C. R. Primmer. 2002. Contemporary fisherian life history evolution in small salmonid populations. Nature. 419: 826-830.

Kottelat M. \& A. J. Whitten. 1996. Freshwater biodiversity in Asia with special reference to fish. World Bank Technical Paper. 343. Washington, USA.

Mayr, E. \& P. D. Ashlock. 1991. Principals of systematic zoology. McGraw Hill Intl. Singapore. 475 p.

Mustafa, S. 1999. Genetic in Sustainable fisheries management. Fishing Newbooks. London. 223 p.

Næsje. Tor F., Jukka A. Vuorinen, \& O. T. Sandlund. 2004. Genetic and morphometric differentiation among sympatric spawning stocks of whitefish (Coregonus lavaretus L.) in Lake Femund, Norway. Journal Limnology. 63 (2): 233-243.

Nelson J. S. 1994. Fishes of the world. 3rd edition. J. Wiley \& sons. New York. p. 600.

Pollnac, R. B. \& S. P. Malvestuto. 1991. Biological and sosio economic conditions for the development and management of riverine fisheries resources in the Kapuas and Musi rivers. p: 24-37. In R. B. Pollnac, C. Baeiley, \& A. Purnomo. 1992. Contribution to Fishery Development Policy in Indonesia. The Central Research Institute for Fisheries. Agency for Agricultural Research and Development. Ministry of Agriculture. Jakarta.

Reist J. D. 1986. An empirical evaluation of coefficients used in residual and allometric adjustment of size covariation. Can. Jour. Zool. 64: 1.363-8.

Schaefer S. A. 1991. Morphometric investigations in cyprinid biology. Cyprinid Fishes: Systematic, biology, and exploitation. I. J. Winfield \& J. S. Nelson (eds.). Chapman and Hall. London. 667 p.

Schluter, D. \& P. R. Grant. 1984. Determinants of morphological patterns in communities of Darwin's finches. Am. Nat. 123: 175-196.

Strauss, R. E \& F. L. Bookstein. 1982. The truss: Body form recontruction in morphometrics. Syst. Zool. 31: 113-135.

Stiassny, M. L. J. \& M. C. C De Pinna. 1994. Basal taxa and the role cladistic patterns in the evolution of conservation priorities: A view from freshwater. In Systematics and conservation (Editors: P. L. Forey, C. J. Humpries, and R. I. Vane-Wright). Cladenron Press. Oxford. Systematics Association Spec. 50: 235-249.

Tilley, S. G., Verrell, P. A., \& Arnold, S. J. 1990. Correspondence between sexual isolation and allozyme differentiation: A test in the salamander Desmognathus ochrophaeus. Proc. Natl. Acad. Sci. USA 87: 2715-2719.

Vuorinen, J., T. F. Næsje, \& O. T. Sandlund. 1991. Genetic changes in a vendace, Coregonus albula, population 92 years after introduction. Journal Fisheries Biologycal. (Suppl. A). 39: 193-201. 